\title{
Ruminacije o pijenju alkohola kao prediktor depresivnosti i alkoholne žudnje kod osoba na bolničkom liječenju od ovisnosti o alkoholu
}

\author{
Nikola Babić \\ Psihijatrijska bolnica Rab, Rab, Hrvatska
}

\section{Sažetak}

Cilj je ovog istraživanja bio ispitati odnose između osjećaja srama zbog pijenja, ruminacija o pijenju, depresivnosti i alkoholne žudnje kod osoba s poremećajem upotrebe alkohola. Klinički uzorak uključivao je 71 pacijenta ( 60 muških) prosječne dobi 49.70 godina $(S D=9.78)$ na bolničkom liječenju od ovisnosti o alkoholu u Psihijatrijskoj bolnici Rab (PBR). Uz sociodemografske podatke korištene su psihologijske mjere osjećaja srama zbog pijenja, ruminacija o pijenju, depresivnosti i alkoholne žudnje. Dobiveni rezultati pokazuju da je viši stupanj osjećaja srama zbog pijenja povezan s višim stupnjevima ruminacija o pijenju i depresinnosti. Osobe koje su više ruminirale bile su depresivnije i izvještavale o većem stupnju alkoholne žudnje, te se i depresivnost pokazala $u$ značajnoj pozitivnoj korelaciji s alkoholnom žudnjom. U predikciji depresivnosti i alkoholne žudnje značajnim su se prediktorom pokazale samo ruminacije o pijenju. Dobiveni rezultati upućuju na važnost ruminacija o pijenju za razumijevanje depresivnosti i alkoholne žudnje kod osoba na liječenju od ovisnosti o alkoholu. Budući da i depresivnost i alkoholna žudnja predstavljaju rizik od recidivizma, ovi nalazi upućuju na potrebu terapijske prorade ruminacija u svrhu povećavanja uspješnosti tretmana poremećaja ovisnosti o alkoholu.

Ključne riječi: sram, ruminacije, depresivnost, alkoholna žudnja, ovisnost o alkoholu

\section{Uvod}

Standardizirano europsko istraživanje o alkoholu iz 2016. otkriva da je 78.1\% ispitanika u Republici Hrvatskoj izjavilo da je pilo alkoholna pića u posljednjih 12 mjeseci, uz značajne razlike po spolu (muškarci $85.3 \%$, žene $71.0 \%$ ) i nešto manje izražene razlike po dobi (18-34 g. - 85.0\%, 35-49 g. - 76.7\%, 50+ g. - 72.2\%). Gotovo polovica ispitanika i oko petine ispitanica izjavilo je da alkohol pije na dnevnoj ili tjednoj bazi. Na temelju brze procjene problema s alkoholom kod 24.2\% muškaraca i $4.8 \%$ žena pronađene su indikacije ovisnosti o alkoholu (Moskalewicz, Room i

Nikola Babić, Psihijatrijska bolnica Rab, Kampor 224, 51280 Rab, Hrvatska. E-pošta: nikobab@gmail.com 
Thom, 2017). U Republici Hrvatskoj vodeći uzroci hospitalizacija iz skupine mentalnih poremećaja 2017. godine bili su upravo mentalni poremećaji uzrokovani alkoholom, s udjelom $18.1 \%$. Prema broju korištenih dana bolničkog liječenja u ukupnom broju dana bolničkog liječenja radi mentalnih poremećaja mentalni poremećaji uzrokovani alkoholom $\mathrm{s}$ udjelom $14.2 \%$ zauzimaju drugo mjesto (Hrvatski zavod za javno zdravstvo, 2017). Priloženi podaci upućuju na to da se radi o poremećaju koji i aktualno predstavlja značajan problem za društvo i pojedinca, iz čega proizlazi i potreba za dodatnim proučavanjem i razumijevanjem istoga.

Žudnja je jedan od osnovnih simptoma ovisnosti koji posljednjih godina privlači pozornost istraživača. Odnosi se na snažno subjektivno iskustvo koje motivira pojedinca da potraži i pronađe svoj cilj ili prakticira određenu aktivnost kako bi postigao željene efekte (Marlatt, 1987). Postoje brojni modeli koji objašnjavaju mehanizme u podlozi žudnje (npr. uvjetovanje, kognitivni mehanizmi itd.), međutim svi se slažu da se radi o multifacetnom fenomenu na koji utječu brojni faktori (Luminet, Cordovil de Sousa Uva, Fantini i de Timary, 2016). Uvođenje žudnje kao novoga dijagnostičkog kriterija za poremećaj ovisnosti u DSM-5 (American Psychiatric Association, 2013) odražava priznanje znanstvene zajednice da žudnja zauzima jednu od ključnih uloga u objašnjavanju ovisnosti. Ovaj je konstrukt odavno identificiran kao važan simptom u poremećaju alkoholizma koji može dovesti do ponašajnog gubitka kontrole (Caselli i sur., 2013), te se smatra ključnim fokusom tretmana alkoholne ovisnosti (O'Malley, Krishnan-Sarin, Farren, Sinha i Kreek, 2002). Pojedina istraživanja izdvajaju alkoholnu žudnju kao važan prediktor recidivizma kod osoba s poremećajem ovisnosti (Oslin, Cary, Slaymaker, Colleran i Blow, 2009), dok kod drugih ta povezanost nije potvrđena (Garbutt i sur., 2009). Dosadašnja istraživanja također pronalaze značajnu povezanost između alkoholne žudnje i: dobi (Hintzen, Cramer, Karagülle i Heberlein, 2011), spola (Boykoff i sur., 2010) i stupnja težine ovisnosti o alkoholu (Umhau i sur., 2011).

Depresivnost i ovisnost o alkoholu povezani su na brojne načine: jedan od poremećaja povećava rizik od razvitka drugog, njihovi su intenziteti međusobno povezani, ovisnost o alkoholu produžava tijek depresivnosti, a održavanje depresivnosti tijekom apstinencije od alkohola faktor je rizika od alkoholnog recidivizma (Pettinati i sur., 2010). Depresivni simptomi povezani su i s maladaptivnim metodama suočavanja $u$ vidu pijenja alkohola i problemskim pijenjem (Bravo, Pearson i Henson, 2017). Oslin i sur. (2009) depresivne simptome (uz stupanj alkoholne žudnje) također smatraju važnim prediktorom recidivizma. Depresija i negativna afektivna stanja povezana su s češćim, intenzivnijim i dugotrajnijim žudnjama za alkoholom (Kavanagh, May i Andrade, 2009). Alkoholna žudnja pokazala se i značajnim medijatorom odnosa između depresivnih simptoma i upotrebe sredstava ovisnosti (Witkiewitz i Bowen, 2010).

Ruminacije se općenito konceptualiziraju kao strategija suočavanja namijenjena kontroli negativnog afekta koju karakterizira povećana pažnja usmjerena na samu osobu. Ova pažnja uključuje namjerno, uporno, repetitivno unutrašnje preispitivanje 
po pitanju uzroka, posljedica i simptoma negativnog afekta kojeg osoba osjeća (npr. "Što ovo znači za mene?", "Zašto ne mogu bolje funkcionirati?", "Zašto se osjećam tako loše?") (Lyubomirsky i Nolen-Hoeksema, 1993). Caselli i sur. (2013) dokazali su i direktnu povezanost ruminacija i alkoholne žudnje. Ovi su autori proveli eksperiment $\mathrm{u}$ kojem su osobe $\mathrm{s}$ poremećajem uzimanja alkohola nasumično podijelili u dvije skupine i zatim manipulirali zadacima: distrakcija u usporedbi s ruminacijama. Alkoholnu žudnju mjerili su prije i poslije zadataka te su dokazali direktan uzročno-posljedični odnos između ruminacija i alkoholne žudnje, specifičan za populaciju ovisnika o alkoholu.

Objašnjenje povezanosti ruminacija i depresivnosti pozitivnim i negativnim metakognitivnim vjerovanjima u svom metakognitivnom modelu depresivnosti pružili su i autori Papageorgiou i Wells (2003). Metakognitivni model depresivnosti započinje okidačem (npr. u kontekstu ovog istraživanja kada osobe otkriju da se njihovo sadašnje stanje razlikuje od očekivanog - aktualno pijenje u suprotnosti sa željenom apstinencijom) koji inicira pozitivna metakognitivna vjerovanja o korisnosti ruminacija kao načinu za razumijevanje $i$ nadilaženje svojih "nedostataka". Slijede ruminacije, a zatim, prema modelu, i negativna metakognitivna vjerovanja o nekontrolabilnosti i štetnosti ruminacija te njihovim interpersonalnim i socijalnim posljedicama. Ruminativno razmišljanje može postati maladaptivno jer usmjerava pažnju na prijetnju te potiče na potiskivanje misli ili na izbjegavajuća ponašanja. Ovakav način razmišljanja naziva se sindrom kognitivne pažnje (Wells i Matthews, 1996). Budući da je neuspješan u modifikaciji onesposobljavajućih vjerovanja o "vlastitom ja", povećava dostupnost negativnih informacija i interferira s regulacijom emocija, sindrom kognitivne pažnje rezultira održavanjem negativnih misli i emocija - depresivnosti (Papageorgiou i Wells, 2001).

Osobe koje zloupotrebljavaju alkohol često osjećaju sram. Radi se o emocionalnom odgovoru koji prati ponašanja učinjena pod utjecajem alkohola ili njegove zlouporabe (Scherer, Worthington, Hook i Campana, 2011), a usmjerava se na samu osobu (npr. "Ja sam loša osoba.") (Dearing, Stuewig i Tangney, 2005). Osjećaji srama posebno su štetni za samopoštovanje osobe, dovode do osjećaja beznađa i mogu povećati sklonost osobe da konzumira sredstva ovisnosti u pokušaju suočavanja s tim osjećajem (Yelsma, Brown i Elison, 2002).

Metanalitička istraživanja pokazuju da i ruminacije (Aldao, Nolen-Hoeksema i Schweizer, 2010) i sram (Kim, Thibodeau i Jorgensen, 2011) pokazuju direktnu značajnu povezanost $\mathrm{s}$ depresivnosti. $U$ pojedinim istraživanjima ruminacije se pokazuju značajnim medijatorom odnosa osjećaja srama i depresije (Cheung, Gilbert i Irons, 2004; Orth, Berking i Burkhardt, 2006) u smislu da je viši stupanj srama povezan s višim stupnjem ruminacija te višim stupnjem depresivnosti.

U teorijskoj pozadini ovog istraživanja novi je model, čija je svrha pokušaj objašnjenja povezanosti opisanih varijabli: osjećaja srama zbog pijenja, ruminacija o pijenju, depresivnosti i alkoholne žudnje prikazan na Slici 1 . Iz originalnoga 
metakognitivnog modela depresivnosti izuzimaju se metakognitivna vjerovanja (koja nisu predmet ovog istraživanja) te nadograđuju varijable osjećaja srama zbog pijenja (za koji se pretpostavlja da služi kao okidač za inicijaciju ruminativnog procesa i izravno je povezan s depresivnosti) te alkoholne žudnje (izravno povezane s ruminacijama i depresivnosti).

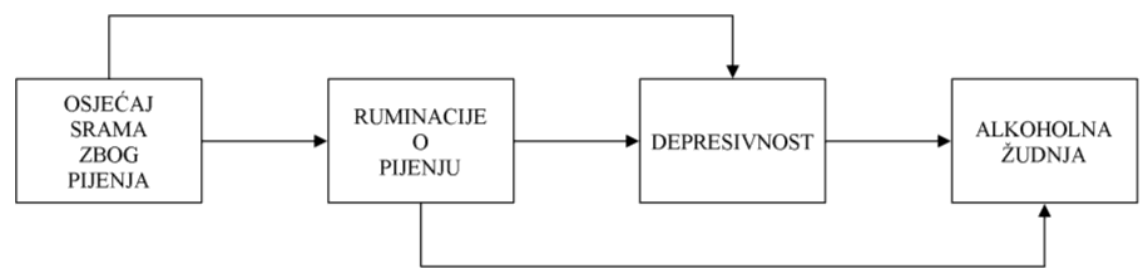

Slika 1. Pretpostavljeni odnos varijabli.

Cilj je ovog istraživanja ispitati povezanost osjećaja srama zbog pijenja, ruminacija o pijenju, depresivnosti i alkoholne žudnje kod pacijenata na bolničkom liječenju od ovisnosti o alkoholu. Nadalje, želimo ispitati ulogu osjećaja srama zbog pijenja i ruminacija o pijenju u objašnjenju depresivnosti te ruminacija o pijenju i depresivnosti u objašnjenju alkoholne žudnje kod istih ispitanika.

$\mathrm{Na}$ ovaj način želimo provjeriti u kojoj je mjeri ovisnost o alkoholu sama po sebi (putem osjećaja srama zbog iste i ruminacijama o istoj) generator procesa koji podržavaju i održavaju ciklus ovisničkog ponašanja - depresivnosti i alkoholne žudnje.

Postavljene su hipoteze da će osjećaj srama zbog pijenja, ruminacije o pijenju i depresivnost te ruminacije o pijenju, depresivnost i alkoholna žudnja biti u značajnoj pozitivnoj korelaciji. Nadalje, pretpostavlja se da će se osjećaj srama zbog pijenja i ruminacije o pijenju pokazati značajnim prediktorima depresivnosti te da će se ruminacije o pijenju i depresivnost pokazati značajnim prediktorima alkoholne žudnje kod pacijenata na bolničkom liječenju ovisnosti o alkoholu. Kao kontrolne varijable u ovom istraživanju korištene su varijable dobi, spola i broja liječenja od ovisnosti o alkoholu.

\section{Metoda}

\section{Sudionici}

Uzorak se sastoji od 71 pacijenta (60 muških) na bolničkom liječenju od ovisnosti o alkoholu u Psihijatrijskoj bolnici Rab- PBR. Dob je ispitanika u rasponu od 22 do 72 godine $(M=49.70, S D=9.78)$. Unutar uzorka $40.3 \%$ ispitanika je zaposleno, $32.8 \%$ nezaposleno, a $26.9 \%$ u mirovini. Većina ispitanika $(77.6 \%)$ srednje je stručne spreme. Po pitanju bračnog statusa $41.8 \%$ ispitanika je oženjeno, 
$4.5 \%$ živi u izvanbračnoj zajednici, $28.4 \%$ razvedeno, $7.5 \%$ su udovci, a $17.9 \%$ neoženjeno. Najveći broj ispitanika (61.2\%) svoje materijalno stanje procjenjuje prosječnim, $19.4 \%$ ispod prosječnim, $11.9 \%$ izrazito ispod prosječnim, a $7.5 \%$ iznad prosječnim. Za $22.4 \%$ ispitanika ovo je prvo liječenje ovisnosti o alkoholu, $19.4 \%$ drugo, $17.9 \%$ treće, $10.4 \%$ četvrto, a za gotovo trećinu ispitanika (29.9\%) peto ili više.

Svi pacijenti s dijagnozom alkoholne ovisnosti registrirani su od strane ispitivača prilikom prijema u bolnicu te su iz daljnjeg odabira ispitanika isključeni pacijenti s komorbidnim dijagnozama nekih od psihotičnih poremećaja ili ovisnosti o drugim psihoaktivnim tvarima (isključujući cigarete i marihuanu). U drugom je koraku ispitivač obavio individualni uvodni intervju sa svakim pacijentom prilikom kojeg su provjeravani slijedeći kriteriji uključivanja: dijagnoza alkoholne ovisnosti, konzumacija alkohola u posljednjih 30 dana te nepostojanje značajnijega neuropsihološkog oštećenja. Onim pacijentima koji su zadovoljili i ove kriterije objašnjeni su priroda i zahtjevi istraživanja te su pozvani na sudjelovanje $u$ istom. Svi su pozvani pacijenti pristali sudjelovati u istraživanju, potpisali su obrazac informiranog pristanka za sudionika i suglasnost za sudjelovanje te ispunili sociodemografski upitnik. Od registriranih 184 pacijenata, s obzirom na zadane kriterije, u istraživanje je uključeno njih 75 . Tijekom provođenja istraživanja četiri ispitanika samoinicijativno napušta liječenje te se konačni uzorak sastoji od 71 ispitanika (38.59\% od svih registriranih).

\section{Postupak}

Prije početka prikupljanja podataka provedeno je predistraživanje u svrhu potvrde metrijskih karakteristika skala, koje su po prvi put prevedene na hrvatski jezik, što je opisano u Rezultatima.

Podaci su prikupljani tijekom bolničkog liječenja ovisnosti o alkoholu u PBRu. U trećem tjednu tretmana (kako bi se izbjegao biološki aspekt žudnje za alkoholom) ispitanici su bili individualno pozvani kod ispitivača te su ispunjavali samoprocjenske upitnike osjećaja srama zbog ovisničkog ponašanja, ruminacija o pijenju, depresivnosti i alkoholne žudnje.

\section{Instrumenti}

Upitnik sociodemografskih podataka konstruiran je u svrhu utvrđivanja nekih obilježja sudionika (dob, spol, poslovni i bračni status, stručna sprema, procjena materijalnog stanja, broj liječenja ovisnosti o alkoholu).

Skala srama i krivnje kao stanja (engl. State Shame and Guilt Scale; Marschall, Sanftner i Tangney, 1994) razvijena je s ciljem mjerenja osjećaja srama i krivnje kao trenutnog stanja. Uputa je modificirana na način da se od ispitanika traži da procjenjuju svoje osjećaje u situaciji kada razmišljaju o svom pijenju alkohola. Cilj 
je ovog istraživanja ispitati isključivo osjećaj srama, pa supskala krivnje nije korištena. Supskala srama sastoji se od 5 čestica $(\alpha=.87)$. Od ispitanika se traži da na skali od 0 (uopće ne) do 4 (izrazito jako) procijene u kojoj mjeri osjećaju emocije vezane za sram kada razmišljaju o svom pijenju alkohola (primjer: "Osjećam se manje vrijedno."). Viši rezultat upućuje na viši stupanj srama.

Skala ruminacije o interpersonalnom prijestupu (engl. Rumination about an Intepersonal Offense Scale; Wade, Vogel, Liao i Goldman, 2008) razvijena je s ciljem mjerenja ruminacije fokusirane na specifičnu situaciju (u suprotnosti $s$ uobičajenim mjerenjem dispozicije za ruminiranje). Originalna je verzija upitnika za mjerenje ruminacije o interpersonalnom prijestupu modificirana na način da se od ispitanika tražilo da procjenjuju svoje ruminacije o pijenju alkohola. Ova se jednofaktorska skala sastoji od šest čestica $(\alpha=.92)$. Od ispitanika se traži da na skali od 1 (uopće se ne slažem) do 5 (potpuno se slažem) procijene svoje slaganje s pojedinim tvrdnjama koje se odnose na pijenje alkohola tijekom proteklog tjedna (primjer: "Ne mogu prestati razmišljati o svom pijenju alkohola."). Viši rezultat upućuje na viši stupanj ruminacija o pijenju alkohola.

Beckov inventar depresivnosti (engl. Beck Depression Inventory BDI-II; Beck, Steer i Brown, 2009) razvijen je kao indikator postojanja i jačine depresivnih simptoma. Ova se jednofaktorska skala sastoji od 21 čestice $(\alpha=.97)$. Od ispitanika se traži da od ponuđene četiri tvrdnje za svaki simptom depresije (od 0 do 3 , veći je broj povezan s većim intenzitetom simptoma) odabere jednu koja najbolje opisuje način na koji se osjećao protekla dva tjedna, uključujući i dan ispunjavanja. Viši rezultat na upitniku sugerira viši stupanj depresivnosti.

Penn skala žudnje za alkoholom (engl. Penn Alcohol Craving Scale; Flannery, Volpicelli i Pettinati, 1999) je jednofaktorska skala za procjenu žudnje za alkoholom, a sastoji se od pet čestica $(\alpha=.92)$. Od ispitanika se traži da na skali od 0 do 6 procjenjuje učestalost, intenzitet i trajanje misli o pijenju te sposobnost da se osoba odupre pijenju (primjer čestice: "Koliko jaka je bila Vaša žudnja na svom vrhuncu tijekom proteklog tjedna?" 0 - Nije postojala, 1 - Blaga, tj. vrlo blagi poriv, 2 - Blagi poriv, 3 - Umjereni poriv, 4 - Snažan poriv, ali koji se mogao lako kontrolirati, 5 Snažan poriv, težak za kontrolirati, 6 - Snažan poriv tako da bih popio alkohol da je bio dostupan). Posljednja čestica traži od ispitanika da procijeni u prosjeku svoju žudnju u posljednjih tjedan dana. Viši rezultat na upitniku upućuje na viši stupanj alkoholne žudnje.

\section{Rezultati}

Statistička analiza provedena je koristeći IBM SPSS Statistics for Windows, Version 20.0 (IBM Corp. Released i SPSS, 2011). 


\section{Predistraživanje}

Korišteni su podaci prikupljeni u sklopu šireg istraživanja za čije su potrebe neki mjerni instrumenti (skala srama, skala ruminacija, skala žudnje za alkoholom) po prvi put prevedeni na hrvatski jezik. Iz tog je razloga bilo potrebno provesti preliminarni dio istraživanja koji je obuhvaćao provjeru njihovih metrijskih karakteristika. Korišten je unazadni prijevod čestica te su skale, nakon što su stručni prevoditelji hrvatske prijevode ponovno preveli na engleski jezik, poslane na provjeru njihovim autorima. Nakon konzultacija s autorima skale su primijenjene na uzorku bolničkih pacijenata PBR-a na liječenju od ovisnosti o alkoholu (odabranih po kriterijima glavnog istraživanja), koji je činilo 94 pacijenata od čega 84 muškaraca i 10 žena, prosječne dobi $M=51.76(S D=11.61)$. Istraživanje je provodio klinički psiholog Psihijatrijske bolnice Rab. Ispitanici u uzorku bili su podjednako raspoređeni po poslovnom statusu (zaposlen, nezaposlen, u mirovini) te je većina (63.80\%) imala završenu srednju školu. Podaci su prikupljani grupno, a sudjelovanje $\mathrm{u}$ ispitivanju bilo je dobrovoljno i anonimno. Prilikom provjere faktorskih struktura zadržane su originalne jednofaktorske strukture svih upitnika. Predispitivanjem su utvrđene vrlo zadovoljavajuće mjerne karakteristike svih skala te se uz suglasnost Etičkog povjerenstva započelo s istraživanjem.

Aritmetičke sredine, standardne devijacije, rasponi i koeficijenti pouzdanosti za sve upitnike samoprocjene prikupljeni u istraživanju prikazani su u Tablici 1.

Tablica 1.

Aritmetičke sredine, standardne devijacije, rasponi i Cronbach alpha koeficijenti za sve upitnike samoprocjene prikupljene u istraživanju

\begin{tabular}{lccccc}
\hline Ime upitnika & $\begin{array}{c}\text { Broj } \\
\text { čestica }\end{array}$ & $M$ & $S D$ & Raspon & $\begin{array}{c}\text { Pouzdanost } \\
\text { (Cronbach } \\
\text { alpha) }\end{array}$ \\
\hline $\begin{array}{l}\text { Skale srama i krivnje kao } \\
\text { stanja - subskala srama }\end{array}$ & 5 & 8.35 & 6.04 & $0-20$ & .87 \\
\hline $\begin{array}{l}\text { Skala ruminacije o } \\
\text { pijenju alkohola }\end{array}$ & 6 & 16.29 & 6.46 & $6-30$ & .82 \\
\hline $\begin{array}{l}\text { Beckov inventar } \\
\text { depresivnosti }\end{array}$ & 21 & 13.24 & 9.95 & $0-45$ & .91 \\
\hline $\begin{array}{l}\text { Penn skala žudnje za } \\
\text { alkoholom }\end{array}$ & 5 & 3.89 & 5.13 & $0-27$ & .95 \\
\hline
\end{tabular}

\section{Povezanost kontrolnih varijabli, osjećaja srama, ruminacija o pijenju, depresivnosti i alkoholne žudnje}

Kako bi se utvrdili obrasci povezanosti između demografskih karakteristika sudionika (dob i spol) i broja liječenja ovisnosti o alkoholu (kontrolne varijable) te osjećaja srama zbog pijenja, ruminacija o pijenju, depresivnosti i alkoholne žudnje, 
u Tablici 2. prikazani su koeficijenti bivarijatnih korelacija među mjerenim varijablama.

Tablica 2.

Povezanost kontrolnih varijabli, osjećaja srama, ruminacija o pijenju, depresivnosti $i$ alkoholne žudnje

\begin{tabular}{|c|c|c|c|c|c|c|c|}
\hline & 1. & 2. & 3. & 4. & 5. & 6. & 7. \\
\hline 1. Dob & - & & & & & & \\
\hline 2. $\operatorname{Spol}(M=0, Z ̌=1)$ & $-.30^{*}$ & - & & & & & \\
\hline $\begin{array}{l}\text { 3. Broj liječenja } \\
\text { ovisnosti o alkoholu }\end{array}$ & .09 & .06 & - & & & & \\
\hline $\begin{array}{l}\text { 4. Osjećaj srama zbog } \\
\text { pijenja }\end{array}$ & .10 & .10 & .22 & - & & & \\
\hline 5. Ruminacije o pijenju & .07 & -.03 & $.25^{*}$ & $.27^{*}$ & & & \\
\hline 6. Depresivnost & -.05 & .08 & $.26^{*}$ & $.31^{* *}$ & $.56^{* *}$ & - & \\
\hline 7. Alkoholna žudnja & -.18 & .18 & $.28^{*}$ & .00 & $.47^{* *}$ & $.33^{* *}$ & - \\
\hline
\end{tabular}
${ }^{*} p<.05 ;{ }^{* *} p<.01$.

Dobiveni koeficijenti korelacije upućuju na to da su ispitanici s većim brojem liječenja opisivali viši stupanj ruminacija o pijenju alkohola, depresivnosti i alkoholne žudnje. Viši stupanj srama povezan je s višim stupnjem ruminacija o pijenju alkohola i depresivnosti. Viši stupanj ruminacija o pijenju alkohola povezan je s višim stupnjem depresivnosti i alkoholne žudnje, te je viši stupanj depresivnosti povezan i s višim stupnjem alkoholne žudnje.

\section{Doprinos broja liječenja od ovisnosti o alkoholu, osjećaja srama zbog pijenja i ruminacija o pijenju u objašnjenju depresivnosti}

Kako bi se provjerilo u kojoj mjeri kontrolne varijable, osjećaj srama zbog pijenja i ruminacije pridonose objašnjenju depresivnosti kod osoba na bolničkom liječenju od ovisnosti o alkoholu, provedena je hijerarhijska regresijska analiza (Tablica 3.). U hijerarhijskoj regresijskoj analizi u prvu je skupinu od kontrolnih varijabli [mjerenih demografskih karakteristika (spol i dob) te broja liječenja od ovisnosti o alkoholu] zbog neznačajnih korelacija uključena jedino varijabla broja liječenja od ovisnosti o alkoholu. U drugom je koraku kao prediktor uključena varijabla osjećaja srama zbog pijenja, a u trećem ruminacije o pijenju. Varijabla osjećaja srama zbog pijenja uvedena je prije ruminacija o pijenju jer se pretpostavlja da osjećaj srama zbog pijenja prethodi ruminacijama (služi kao okidač za početak ruminativnog procesa). 
Tablica 3.

Rezultati hijerarhijske regresijske analize s brojem liječenja od ovisnosti o alkoholu, osjećaju srama zbog pijenja i ruminacijama o pijenju kao prediktorima depresivnosti

\begin{tabular}{|c|c|c|c|}
\hline \multicolumn{4}{|c|}{ Kriterijska varijabla - depresivnost } \\
\hline Prediktorske varijable & $\beta$ & $\Delta R^{2}$ & $R^{2}$ \\
\hline \multicolumn{4}{|l|}{ 1. korak } \\
\hline Broj liječenja od ovisnosti o alkoholu & $.26^{*}$ & .05 & $.05^{*}$ \\
\hline \multicolumn{4}{|l|}{ 2. korak } \\
\hline Broj liječenja od ovisnosti o alkoholu & .20 & .06 & $.11^{*}$ \\
\hline Osjećaj srama zbog pijenja & $.26^{*}$ & & \\
\hline \multicolumn{4}{|l|}{ 3. korak } \\
\hline Broj liječenja od ovisnosti o alkoholu & .10 & .21 & $.32^{* * *}$ \\
\hline Osjećaj srama zbog pijenja & .15 & & \\
\hline Ruminacije o pijenju & $.50^{* * * *}$ & & \\
\hline
\end{tabular}

${ }^{*} p<.05 ;{ }^{* *} p<.01 ;{ }^{* * * *} p<.001$.

Rezultati hijerarhijske regresijske analize u prvom koraku upućuju na to da broj liječenja od ovisnosti o alkoholu $(\beta=.26)$ značajno pridonosi i objašnjava $5 \%$ varijance depresivnosti. Uvođenjem se srama zbog pijenja $(\beta=.42) \mathrm{u}$ drugom koraku postotak objašnjene varijance povećava za dodatnih $6 \%$ varijance, međutim broj liječenja od ovisnosti o alkoholu gubi svoju statističku značajnost, što upućuje na prisutnost supresorskih efekata. U trećem se koraku uvode ruminacije o pijenju koje dodatno i značajno povećavaju postotak objašnjene varijance za $21 \%(\beta=.50)$, međutim osjećaj srama zbog pijenja gubi na značajnosti, što također upućuje na prisutnost supresorskih efekata. Zaključno, zadanim je skupom prediktorskih varijabli moguće objasniti $32 \%$ varijance depresivnosti. Pritom su jedini značajni prediktor ruminacije o pijenju $(\beta=.50)$. Dobiveni rezultati sugeriraju da osobe koje više ruminiraju o pijenju izvještavaju o većem stupnju depresivnosti.

\section{Doprinos broja liječenja od ovisnosti o alkoholu, ruminacija i depresivnosti u objašnjenju alkoholne žudnje}

Kako bi se provjerilo u kojoj mjeri kontrolne varijable, ruminacije o pijenju i depresivnost pridonose objašnjenju alkoholne žudnje kod osoba na bolničkom liječenju od ovisnosti o alkoholu, provedena je hijerarhijska regresijska analiza (Tablica 4.). U hijerarhijskoj regresijskoj analizi u prvu je skupinu od kontrolnih varijabli [mjerenih demografskih karakteristika (spol i dob) te broja liječenja od ovisnosti o alkoholu] zbog neznačajnih korelacija uključena jedino varijabla broja liječenja od ovisnosti o alkoholu. U drugoj su skupini prediktora uključene ruminacije o pijenju, a u trećoj depresivnost. Varijabla ruminacija o pijenju uvedena je prije depresivnosti jer metakognitivni model depresivnosti pretpostavlja da ruminacije prethode depresivnosti. 
Tablica 4.

Rezultati hijerarhijske regresijske analize s brojem liječenja od ovisnosti o alkoholu, ruminacijama o pijenju i depresivnosti kao prediktorima alkoholne žudnje

\begin{tabular}{llll}
\hline \multicolumn{4}{c}{ Kriterijska varijabla - depresivnost } \\
\hline Prediktorske varijable & $\beta$ & $\Delta R^{2}$ & $R^{2}$ \\
\hline $\begin{array}{l}\text { 1. korak } \\
\text { Broj liječenja od ovisnosti o alkoholu }\end{array}$ & .28 & .08 & $.08^{*}$ \\
\hline $\begin{array}{l}\text { 2. korak } \\
\text { Broj liječenja od ovisnosti o alkoholu }\end{array}$ & .17 & .16 & $.25^{* * *}$ \\
$\quad$ Ruminacije o pijenju & $.42^{* * *}$ & & \\
\hline 3. korak & & & $.25^{* * *}$ \\
Broj liječenja od ovisnosti o alkoholu & .16 & .00 & \\
Ruminacije o pijenju & $.39^{* * *}$ & & \\
Depresivnost & .07 & & \\
\hline
\end{tabular}

${ }^{*} p<.05 ;{ }^{* *} p<.01 ;{ }^{* * *} p<.001$.

Rezultati hijerarhijske regresijske analize u prvom koraku upućuju na to da broj liječenja od ovisnosti o alkoholu $(\beta=.28)$ značajno pridonosi i objašnjava $8 \%$ varijance alkoholne žudnje. Uvođenjem se ruminacija o pijenju $(\beta=.42)$ u drugom koraku postotak objašnjene varijance povećava za dodatnih $16 \%$ varijance, međutim broj liječenja od ovisnosti o alkoholu gubi svoju statističku značajnost, što upućuje na prisutnost supresorskih efekata. U trećem se koraku uvodi depresivnost koja značajno ne doprinosi objašnjenju alkoholne žudnje na našem uzorku, dok ruminacije $(\beta=.39)$ ne gube na značajnosti. Zaključno, zadanim je skupom prediktorskih varijabli moguće objasniti $25 \%$ varijance alkoholne žudnje. Pritom su jedini značajni prediktor ruminacije o pijenju $(\beta=.39)$. Dobiveni rezultati sugeriraju da osobe koje više ruminiraju o pijenju izvještavaju o većoj žudnji za alkoholom.

\section{Rasprava}

Cilj je ovog istraživanja bio ispitati povezanost osjećaja srama zbog pijenja, ruminacija o pijenju, depresivnosti i alkoholne žudnje te ispitati ulogu izmjerenih varijabli u predikciji depresivnosti i alkoholne žudnje kod pacijenata na bolničkom liječenju od ovisnosti o alkoholu.

Među uključenim je kontrolnim varijablama varijabla broja liječenja ovisnosti o alkoholu pokazala značajnu pozitivnu povezanost $\mathrm{s}$ varijablama ruminacija o pijenju, depresivnosti i alkoholne žudnje. Pacijenti s "dugogodišnjim stažem" i višekratnim iskustvom liječenja, a samim time i češći recidivisti (što također upućuje na stupanj težine alkoholne ovisnosti), u većoj su mjeri ruminirali o pijenju i izvještavali o većem stupnju žudnje za alkoholom. Česti se komorbiditeti između 
depresivnosti i ovisnosti o alkoholu odražavaju i u ovoj značajnoj pozitivnoj povezanosti broja liječenja od ovisnosti o alkoholu i depresivnosti.

Značajne pozitivne korelacije između srama zbog pijenja, ruminacija o pijenju i depresivnosti, zatim ruminacija o pijenju, depresivnosti i alkoholne žudnje, te depresivnosti i alkoholne žudnje idu u prilog postavljenim hipotezama i pretpostavljenom odnosu varijabli opisanom u uvodu. Osjećaj srama zbog pijenja povezan je s većom razinom ruminacija o pijenju. Prema metakognitivnom modelu depresivnosti ova se povezanost može objasniti time da osjećaj srama, koji sam po sebi predstavlja značajnu emocionalnu nelagodu, služi kao okidač za ruminativni proces čiji je cilj razumijevanje i nadilaženje diskrepance između sadašnjeg i željenog stanja (Papageorgiou i Wells, 2003). Dakle, ispitanici ovog istraživanja, uslijed neugodnog osjećaja srama zbog pijenja i njihova ponašanja vezanog za pijenje, imaju potrebu razmišljati o istome kako bi pronašli neki vid emocionalne ventilacije koja bi tu istu neugodu umanjila. Isti model objašnjava i najsnažniju pozitivnu povezanost dobivenu u ovom istraživanju - između ruminacija i depresivnosti. Budući da ruminacije povećavaju dostupnost negativnih informacija i interferiraju s regulacijom emocija, u sklopu sindroma kognitivne pažnje rezultiraju i održavanjem depresivnosti. Razmišljanje o pijenju, koje je primarno inicirano kako bi umanjilo emocionalnu nelagodu, na kraju postaje maladaptivno te rezultira održavanjem negativnog afekta. Pozitivnu korelaciju između osjećaja srama zbog pijenja i depresivnosti također možemo objasniti preko povezanosti srama i ruminacija koje su se pokazale prediktorom depresivnih reakcija na negativne događaje (Nolen-Hoeksema, 2000). U skladu s dosadašnjim istraživanjima (Caselli i sur., 2013) ruminacije o pijenju, kao i depresivnost, pokazuju značajnu pozitivnu povezanost i s alkoholnom žudnjom. Razmišljanje o pijenju i održavanje misli vezanih za pijenje u svijesti rezultiraju željom za daljnjim pijenjem. Ovaj proces kod osoba oboljelih od poremećaja ovisnosti o alkoholu dodatno olakšava njihova sklonost emocijama usmjerenim suočavanjem s negativnim afektom (depresivnosti) kroz pijenje (Kavanagh i sur., 2009).

$\mathrm{U}$ predikciji depresivnosti isprva se značajnim prediktorom s relativnom skromnim doprinosom pokazuje varijabla broja liječenja od ovisnosti o alkoholu, dok se ta značajnost gubi kad se u analizu uvede varijabla osjećaja srama zbog pijenja. Ovaj podatak upućuje na to da je jačina ovisnosti o alkoholu povezana $s$ izraženosti depresivnih simptoma upravo putem osjećaja srama, koji je intenzivniji kod osoba koje duže i teže boluju od poremećaja ovisnosti o alkoholu. Međutim, i osjećaj srama gubi na značajnosti u predikciji depresivnosti kad se u analizu u trećem koraku uvedu ruminacije o pijenju, što upućuje na to da značajan dio povezanosti srama i depresivnosti objašnjava upravo ruminativni proces opetovanog razmišljanja o ponašanju kojeg se osoba srami. Ovom se skupinom varijabli zaključno objašnjava gotovo trećina varijance depresivnosti osoba na liječenju od ovisnosti o alkoholu.

U predikciji alkoholne žudnje također se u prvom koraku značajnim prediktorom, s relativno malim doprinosom, pokazuje varijabla broja liječenja od 
ovisnosti o alkoholu, što odražava logičku povezanost jačine ovisnosti o alkoholu i želje za daljnjim pijenjem. Broj liječenja od ovisnosti gubi na značajnosti u predikciji alkoholne žudnje kada se u analizu uvede varijabla ruminacija o pijenju, što upućuje na to da znatan dio povezanosti jačine ovisnosti $i$ alkoholne žudnje objašnjava upravo proces razmišljanja o pijenju alkohola. Osobe koje teže i duže boluju od alkoholne ovisnosti češće i razmišljaju o pijenju, što dovodi i do većeg poriva za uzimanjem alkohola. Rezultati ove analize pokazuju i da povezanost ruminacija o pijenju i alkoholne žudnje vrlo vjerojatno objašnjava i značajan dio povezanosti depresivnosti i alkoholne žudnje, jer, iako su se depresivnost $i$ alkoholna žudnja pokazali značajno pozitivno povezanima, uvođenje depresivnosti u analizu u trećem koraku značajno ne doprinosi objašnjenju alkoholne žudnje. Ovom se skupinom varijabli zaključno objašnjava četvrtina varijance alkoholne žudnje kod osoba na liječenju od ovisnosti o alkoholu.

Caselli i sur. (2013) predlažu objašnjenje povezanosti ruminacija i alkoholne žudnje u smislu da žudnja za alkoholom predstavlja kognitivnu regulatornu strategiju usmjerenu kontroli ruminacija kao takvih. Međutim, suprotno tome, alkohol ima sasvim obrnut, održavajući efekt iz dva razloga. Kao prvo, ometa metakognitivno nadgledanje, koje je ključna vještina fleksibilne samoregulacije stila razmišljanja (Spada i Wells, 2009). Nadalje, pijenje alkohola može inducirati i depresiju, koja može poslužiti kao okidač za buduće ruminiranje.

Dobiveni rezultati idu u prilog pretpostavljenom odnosu varijabli prikazanom u novom modelu koji predstavlja znanstveni doprinos ovog rada. Ovaj model djelomično testira i nadograđuje metakognitivni model depresivnosti Papageorgiou i Wells (2003) primijenjen na populaciju osoba oboljelih od ovisnosti o alkoholu. Osobe koje prilikom liječenja od ovisnosti o alkoholu budu osjećale višu razinu srama zbog svog pijenja češće će razmišljati o samom pijenju, što će dovesti do više razine depresivnosti kod istih. Nadalje, osobe koje budu češće razmišljale o svom pijenju bit će depresivnije te istovremeno osjećati višu razinu žudnje za alkoholom.

U kliničkom kontekstu rezultati ovog istraživanja upućuju na to da procjena i intervencija po pitanju ruminacija može biti korisna u tretmanu alkoholne ovisnosti te $\mathrm{s}$ njom uparene depresivnosti. Učenje vještina koje smanjuju razinu ruminacija mogu imati utjecaj i na smanjivanje razine alkoholne žudnje i depresivnosti. Metakognitivna terapija (Wells, 2009) i bihevioralno-kognitivna terapija usmjerena na ruminacije (Watkins, 2016) pokazuju dobre rezultate u smanjenju razine depresivnosti i ruminacije, i samim time pokazuju potencijal i za tretman alkoholne ovisnosti. Spomenuta metakognitivna terapija ističe važnost rada na misaonim procesima pri čemu se ovladava načinima prekidanja ruminacije i jačanja metakognitivnih vještina kojima se klijent distancira od negativnih misli. Dobre rezultate u smislu adekvatnog suočavanja s ruminacijama pokazuje i kognitivna terapija usredotočene svjesnosti (Teasdale i sur., 2000).

Jedno je od ograničenja ovog istraživanja nemogućnost generalizacije rezultata. Naime, prilikom selekcije ispitanika manje od $40 \%$ je zadovoljilo kriterije 
uključivanja u istraživanje, što upućuje na to da je naš uzorak dobrim dijelom selekcioniran i u manjoj mjeri odražava karakteristike populacije pacijenata koji dolaze na liječenje od ovisnosti o alkoholu. Najčešći razlozi za ovakvo značajno odbacivanje ispitanika bili su politoksikomanija, dijagnoza nekog od psihotičnih poremećaja i značajnije neurokognitivno oštećenje. Ovaj podatak upućuje i na heterogenost skupine pacijenata s problemom ovisnosti o alkoholu, što implicira i zahtjevnost tretmana ovoga složenog poremećaja. Nadalje, ove su varijable izmjerene u bolničkoj sredini, u trenutku kad su osobe već započele s tretmanom, što može utjecati na gotovo sve uključene varijable (npr. umanjiti osjećaj srama s obzirom na to da sam čin pristupanja tretmanu može popraviti sliku o "vlastitom ja" jer osoba ne nastavlja s nepoželjnim ponašanjem itd.). Također, radi se o relativno malom, kliničkom uzorku, koji ne dozvoljava provjeru pretpostavljenog modela u cjelini.

Iznosimo i neke implikacije za buduća istraživanja. Veći broj ispitanika omogućio bi provjeru novog modela u cjelini, a podatak o apstinenciji tj. recidivizmu nakon liječenja omogućio bi bolje razumijevanje efekata varijabli uključenih u ovo istraživanje na održavanje ovisnosti o alkoholu.

Zaključno, rezultati ovog istraživanja kod pacijenata na bolničkom liječenju od ovisnosti o alkoholu izdvajaju ruminacije kao značajan prediktor u objašnjenju depresivnosti i alkoholne žudnje, dva rizična faktora za recidivizam (Oslin i sur., 2009). Ovi nalazi potvrđuju važnost ruminacija u nastanku i održavanju alkoholne ovisnosti te upućuju na to da bi zahvaćanje ovog procesa moglo poboljšati ishode terapijskog rada s osobama oboljelim od poremećaja ovisnosti o alkoholu.

\section{Literatura}

Aldao, A., Nolen-Hoeksema, S. i Schweizer, S. (2010). Emotion-regulation strategies across psychopathology: A meta-analytic review. Clinical Psychology Review, 30(2), 217-237. https://doi.org/10.1016/j.cpr.2009.11.004

American Psychiatric Association. (2013). Diagnostic and statistical manual of mental disorders 5th. American Journal of Psychiatry. https://doi.org/10.1176/appi.books. 9780890425596.744053

Beck, A. T., Steer, R. A. i Brown, G. K. (2009). Beckov inventar depresije-II - BDI-II. Jastrebarsko: Naklada Slap.

Boykoff, N., Schneekloth, T. D., Hall-Flavin, D., Loukianova, L., Karpyak, V. M., Stevens, S. R., Biernacka, J. M., Mrazek, D. A. i Frye, M. A. (2010). Gender differences in the relationship between depressive symptoms and cravings in alcoholism. American Journal on Addictions, 19(4), 352-356. https://doi.org/10.1111/j.1521-0391.2010. 00057.x 
Bravo, A. J., Pearson, M. R. i Henson, J. M. (2017). Drinking to cope with depressive symptoms and ruminative thinking: A multiple mediation model among college students. Substance Use \& Misuse, 52(1), 52-62. https://doi.org/10.1080/10826084. 2016.1214151

Caselli, G., Gemelli, A., Querci, S., Lugli, A. M., Canfora, F., Annovi, C., Rebecchi, D., Ruggiero, G. M., Sassaroli, S., Spada, M. M. i Watkins, E. R. (2013). The effect of rumination on craving across the continuum of drinking behaviour. Addictive Behaviors, 38(12), 2879-2883. https://doi.org/10.1016/j.addbeh.2013.08.023

Cheung, M. S. P., Gilbert, P. i Irons, C. (2004). An exploration of shame, social rank and rumination in relation to depression. Personality and Individual Differences, 36(5), 1143-1153. https://doi.org/10.1016/S0191-8869(03)00206-X

Dearing, R. L., Stuewig, J. i Tangney, J. P. (2005). On the importance of distinguishing shame from guilt: Relations to problematic alcohol and drug use. Addictive Behaviors, 30(7), 1392-1404. https://doi.org/10.1016/j.addbeh.2005.02.002

Flannery, B., Volpicelli, J. R. i Pettinati, H. M. (1999). Psychometric properties of the Penn Alcohol Craving Scale. Alcoholism, Clinical and Experimental Research, 23(8), 12891295. https://doi.org/10.1111/j.1530-0277.1999.tb04349.x

Garbutt, J. C., Osborne, M., Gallop, R., Barkenbus, J., Grace, K., Cody, M., Flannery, B. i Kampov-Polevoy, A. B. (2009). Treatment: Sweet liking phenotype, alcohol craving and response to naltrexone treatment in alcohol dependence. Alcohol and Alcoholism, 44(3), 293-300. https://doi.org/10.1093/alcalc/agn122

Hintzen, A. K., Cramer, J., Karagülle, D. i Heberlein, A. (2011). Does alcohol craving decrease with increasing age? Results from a cross-sectional study. Journal of Studies on Alcohol and Drugs, 72(1), 158-162. https://doi.org/10.15288/jsad.2011.72.158

Hrvatski zavod za javno zdravstvo. (2017). Hrvatski zdravstveno-statistički ljetopis za 2017. godinu. Croatian Health Statistics Yearbook 2017, 417.

IBM Corp. Released. (2011). IBM SPSS Statistics for Windows, Version 20. Armonk, NY: IBM Corp.

Kavanagh, D. J., May, J. i Andrade, J. (2009). Tests of the elaborated intrusion theory of craving and desire: Features of alcohol craving during treatment for an alcohol disorder. British Journal of Clinical Psychology, 48(3), 241-254. https://doi.org/10.1348/ $014466508 \times 387071$

Kim, S., Thibodeau, R. i Jorgensen, R. S. (2011). Shame, guilt, and depressive symptoms: A meta-analytic review. Psychological Bulletin, 137(1), 68-96. https://doi.org/10.1037/ a0021466

Luminet, O., Cordovil de Sousa Uva, M., Fantini, C. i de Timary, P. (2016). The association between depression and craving in alcohol dependency is moderated by gender and by alexithymia factors. Psychiatry Research, 239, 28-33. https://doi.org/10.1016/j. psychres.2016.02.062

Lyubomirsky, S. i Nolen-Hoeksema, S. (1993). Self-perpetuating properties of dysphoric rumination. Journal of Personality and Social Psychology, 65(2), 339-349. http://www.ncbi.nlm.nih.gov/pubmed/8366423 
Marlatt, G. A. (1987). Craving notes. British Journal of Addiction, 82(1), 42-44. https://doi.org/10.1111/j.1360-0443.1987.tb01434.x

Marschall, D., Sanftner, J. i Tangney, J. (1994). State Shame and Guilt Scale. Fairfax, WA: George Mason University.

Moskalewicz, J., Room, R. i Thom, B. (2017). Comparative monitoring of alcohol epidemiology across the EU. Warsaw: Joint Action on Reducing Alcohol Related Harm (RARHA).

Nolen-Hoeksema, S. (2000). The role of rumination in depressive disorders and mixed anxiety/depressive symptoms. Journal of Abnormal Psychology, 109(3), 504-511. https://doi.org/10.1037/0021-843X.109.3.504

O'Malley, S. S., Krishnan-Sarin, S., Farren, C., Sinha, R. i Kreek, M. (2002). Naltrexone decreases craving and alcohol self-administration in alcohol-dependent subjects and activates the hypothalamo-pituitary-adrenocortical axis. Psychopharmacology, 160(1), 19-29. https://doi.org/10.1007/s002130100919

Orth, U., Berking, M. i Burkhardt, S. (2006). Self-conscious emotions and depression: Rumination explains why shame but not guilt is maladaptive. Personality and Social Psychology Bulletin, 32(12), 1608-1619. https://doi.org/10.1177/0146167206292958

Oslin, D. W., Cary, M., Slaymaker, V., Colleran, C. i Blow, F. C. (2009). Daily ratings measures of alcohol craving during an inpatient stay define subtypes of alcohol addiction that predict subsequent risk for resumption of drinking. Drug and Alcohol Dependence, 103(3), 131-136. https://doi.org/10.1016/j.drugalcdep.2009.03.009

Papageorgiou, C. i Wells, A. (2001). Positive beliefs about depressive rumination: Development and preliminary validation of a Self-Report Scale. Behavior Therapy, 32(1), 13-26. https://doi.org/10.1016/S0005-7894(01)80041-1

Papageorgiou, C. i Wells, A. (2003). An empirical test of a clinical metacognitive model of rumination and depression. Cognitive Therapy and Research, 27(3), 261-273. https://doi.org/10.1023/A:1023962332399

Pettinati, H. M., Oslin, D. W., Kampman, K. M., Dundon, W. D., Xie, H., Gallis, T. L., Dackis, M. D. i O'Brien, C. P. (2010). A double-blind, placebo-controlled trial combining sertraline and naltrexone for treating co-occurring depression and alcohol dependence. American Journal of Psychiatry, 167(6), 668-675. https://doi.org/10.1176/ appi.ajp.2009.08060852

Scherer, M., Worthington, E. L., Hook, J. N. i Campana, K. L. (2011). Forgiveness and the bottle: Promoting self-forgiveness in individuals who abuse alcohol. Journal of Addictive Diseases, 30(4), 382-395. https://doi.org/10.1080/10550887.2011.609804

Spada, M. M. i Wells, A. (2009). A metacognitive model of problem drinking. Clinical Psychology and Psychotherapy, 16(5), 383-393. https://doi.org/10.1002/cpp.620

Teasdale, J. D., Segal, Z. V., Williams, J. M. G., Ridgewaya, V. A., Soulsby, J. M. i Lau, M. A. (2000). Prevention of relapse/recurrence in major depression by mindfulness-based cognitive therapy. Journal of Consulting and Clinical Psychology, 68(4), 615-623. https://doi.org/10.1037/0022-006X.68.4.615 
Umhau, J. C., Schwandt, M. L., Usala, J., Geyer, C., Singley, E., George, D. T. i Heilig, M. (2011). Pharmacologically induced alcohol craving in treatment seeking alcoholics correlates with alcoholism severity, but is insensitive to acamprosate. Neuropsychopharmacology, 36(6), 1178-1186. https://doi.org/10.1038/npp.2010.253

Wade, N. G., Vogel, D. L., Liao, K. Y. H. i Goldman, D. B. (2008). Measuring state-specific rumination: Development of the rumination about an Interpersonal Offense Scale. Journal of Counseling Psychology, 55(3), 419-426. https://doi.org/10.1037/00220167.55.3.419

Watkins, E. R. (2016). Rumination-focused cognitive-behavioral therapy for depression. New York, NY: The Guilford Press.

Wells, A. (2009). Metacognitive therapy for anxiety and depression. New York, NY: The Guilford Press.

Wells, A. i Matthews, G. (1996). Modelling cognition in emotional disorder: The S-REF model. Behaviour Research and Therapy, 34(11-12), 881-888. https://doi.org/10.1016/ S0005-7967(96)00050-2

Witkiewitz, K. i Bowen, S. (2010). Depression, craving, and substance use following a randomized trial of mindfulness-based relapse prevention. Journal of Consulting and Clinical Psychology, 78(3), 362-374. https://doi.org/10.1037/a0019172

Yelsma, P., Brown, N. M. i Elison, J. (2002). Shame-focused coping styles and their associations with self-esteem. Psychological Reports, 90(3_suppl), 1179-1189. https://doi.org/10.2466/pr0.2002.90.3c.1179

\title{
Rumination About Drinking as a Predictor of Depression and Alcohol Craving among Inpatients in Treatment of Alcohol Use Disorder
}

\begin{abstract}
The aim of this study was to assess the relationship between feeling of shame related to drinking, rumination about drinking, depression and alcohol craving among psychiatric inpatients with alcohol use disorder (AUD). The clinical sample included 71 inpatients (60 male) average age 49.70 years $(S D=9.78)$ who were hospitalized for AUD treatment disorder in Psychiatric Hospital Rab. Psychological measures included State Shame Scale, Rumination about Drinking Scale, Beck Depression Inventory and Penn Alcohol Craving Scale. The results show that shame related to drinking is associated with rumination about drinking and depression. Rumination about drinking is associated with depression and alcohol craving, and depression is associated with alcohol craving. Rumination about drinking was also significant predictor of depression and alcohol craving. The results suggest that rumination about drinking is significant for understanding depression and alcohol craving among inpatients with AUD. Since both depression and alcohol craving are significant risk factors for relapse after treatment, these finding also suggest that working through rumination as a part of the treatment could improve AUD treatment outcomes.
\end{abstract}

Keywords: shame, rumination, depression, alcohol craving, alcohol use disorder

Primljeno: 7.5.2019. 